\title{
Mártires, héroes y víctimas: estética y política en las imágenes de Santiago Maldonado
}

\section{Martyrs, heroes and victims: aesthetic and politics in the pictures of Santiago Maldonado}

\author{
Mazzuchini, Santiago
}

\section{Santiago Mazzuchini}

santiagomazzuchini@gmail.com

Facultad de Ciencias Sociales. Universidad de Buenos Aires, Argentina

\author{
Avances del Cesor \\ Universidad Nacional de Rosario, Argentina \\ ISSN: $1514-3899$ \\ ISSN-e: 2422-6580 \\ Periodicidad: Semestral \\ vol. 18 , núm. 25,2021 \\ revistaavancesdelcesor@ishir-conicet.gov.ar
}

Recepción: 21 Mayo 2021

Aprobación: 23 Agosto 2021

URL: http://portal.amelica.org/ameli/jatsRepo/27/272643009/ index.html

DOI: https://doi.org/10.35305/ac.v18i25.1537

\section{(i) (9)}

Esta obra está bajo una Licencia Creative Commons AtribuciónNoComercial 4.0 Internacional.
Resumen: Este articulo propone un recorrido y una reflexión teórico-política sobre la iconografía construida alrededor de Santiago Maldonado, con el objetivo de indagar sobre los modos en que la figura del mártir-heroico y el desaparecido perviven y coexisten en diferentes imágenes de protesta. Diversos colectivos de arte político y fotoperiodismo realizaron una amplia variedad de intervenciones visuales para reclamar por la aparición y el posterior esclarecimiento de la muerte de Maldonado, asociando dicha figura con una serie de víctimas asesinadas o desaparecidas por parte del Estado y sus fuerzas de seguridad. Este intento de vincular el caso con una serie previa da cuenta de una estrategia de politización que lo transforma en un problema público, haciendo que la víctima deje de ser anónima (Gayol y Kessler, 2018). Las estrategias visuales destinadas a politizar e intentar instalar el caso en la agenda mediática dejaron como saldo nuevas imágenes que permiten repensar los modos en que el cuerpo de la víctima deviene en un agente activo de protesta. Por otra parte, las acciones visuales se inscriben en una extensa iconografía política ligada a la desaparición y la muerte, donde rostros y siluetas son figuras tradicionales de nuestra imaginación estético-política.

Palabras clave: Iconografía política, Acto de imagen, Memoria, Estética.
Abstract: This article proposes a journey and a theoretical- political reflection on the iconography built around Santiago Maldonado, with the aim of investigating the ways in which the figure of the heroic martyr and the disappeared survive and coexist in different images of protest. Various political art and photojournalism collectives made a wide variety of visual interventions to claim for the appearance and subsequent clarification of Maldonado's death, associating said figure with a series of victims murdered or disappeared by the State and its security forces. This attempt to link the case with a previous series gives account of a politicization strategy that transforms it into a public problem, causing the victim to no longer be anonymous (Gayol and Kessler, 2018). The visual strategies aimed at politicizing and trying to place the case on the media agenda left new images as a balance which allows us to rethink the ways in which the victim's body becomes an active agent of protest. On the other hand, visual actions are part of an extensive political iconography linked to disappearance and death, where faces 
and silhouettes are traditional figures of our aesthetic-political imagination.

Keywords: Political iconography, Image acts, Memory, Aesthetic.

\section{Introducción}

Santiago Maldonado desapareció el 1 de agosto de 2017, en el marco de una protesta situada en Cushamen, provincia de Chubut. El joven de 28 años se encontraba apoyando un reclamo en la ruta 40 , impulsado por la comunidad mapuche Pu Lof en Resistencia. Gendarmería Nacional Argentina llevó a cabo una represión contra los manifestantes y concretó el desalojo de la ruta luego de ingresar al territorio donde se alojaban. Allí los persiguieron hasta la orilla del río. Luego de esa persecución, Santiago Maldonado no fue visto más hasta el hallazgo de su cuerpo, el 17 de octubre del mismo año, a unos metros del lugar.

Esa desaparición, así como la posterior aparición de su cuerpo sin vida, constituye uno de los casos de discusión sobre la violencia estatal y el posicionamiento de los gobiernos sobre los derechos humanos, más trascendente de los últimos años. El hecho fue ocupando, durante varios meses, centralidad en la agenda mediática gracias a la presión de diferentes sectores sociales que militaron para que el caso cobrara relevancia. Y es que para que la demanda por la atención pública se llevara a cabo surgieron diversas movilizaciones en las calles e intervenciones en medios de comunicación y plataformas digitales que incluyeron prácticas ligadas al activismo artístico y otras acciones de protesta. Este conjunto de iniciativas fue evocando una memoria colectiva acerca de las figuras de mártires, héroes y víctimas que componen la historia de la represión y la violencia política en Argentina.

A partir de estas acciones Maldonado fue inscripto en una serie que va desde Julio López ${ }^{1}$, Luciano Arruga ${ }^{2}$, Miguel Bru ${ }^{3}$ (entre otros), hasta los desaparecidos por la dictadura militar, dando cuenta -una vez más- que cuando una persona desaparece y/o es asesinada bajo la responsabilidad de las fuerzas de seguridad, y la noticia comienza a ganar espacios, movimientos de derechos humanos, partidos políticos y otros activismos reactivan el recuerdo de la dictadura cívico militar que, entre 1976 y 1983, ejecutó un plan sistemático de desaparición y exterminio de grupos considerados "subversivos". Las demandas por pedidos de justicia y de "aparición con vida" -histórica consigna de las Madres y Abuelas de Plaza de Mayo- suelen estar articuladas e impulsadas por diferentes movimientos políticos y sociales. Cabe destacar que la figura del familiar -representada en este caso por Sergio Maldonado, hermano de Santiago- como militante o activista de la causa, ha tenido un rol históricamente clave en estos episodios, instituida y validada a través de las Madres y Abuelas, o la agrupación H.I.J.O.S. (Jelin, 2010). Se trata, como indica Jelin (2018), de emprendedores de la memoria.

La desaparición de Santiago puso en el centro de la escena pública este entramado de memorias, expresadas en intervenciones que operaron sobre el trabajo de textos, cuerpos e imágenes de protesta. En este aspecto, el activismo artístico y el fotoperiodismo se han convertido en dos esferas de la praxis que cumplen un papel fundamental para darle cuerpo (social) a las memorias, a partir de rituales y conmemoraciones que disputan los sentidos del pasado, dando 
cuenta que se trata también, como insiste Jelin, de un asunto del presente. A partir de los usos que el activismo inventa cada vez para imprimirle politicidad a la fotografía, o de fotoperiodistas proponiendo acciones en el espacio público, estas dos esferas se convierten en terrenos privilegiados para la elaboración colectiva de una memoria.

Se trata además de un modo de intervención política en contra de la violencia y la reproducción de la desigualdad social, que se expresa también en un desigual reconocimiento de los cuerpos que merecen ser reconocidos como víctimas.

\section{Enfoque teórico-metodológico: acerca de un modo de trabajo con las imágenes}

En el largo comentario sobre Las meninas (Diego Velázquez, 1656) que se encuentra en Las palabras y las cosas, Foucault (2002) realiza una interesante observación a propósito de los vínculos entre el lenguaje y la pintura, que invita a pensar a las imágenes en su no lineal relación con las palabras:

Pero la relación del lenguaje con la pintura es una relación infinita. No porque la palabra sea imperfecta y, frente a lo visible, tenga un déficit que se empeñe en vano por recuperar. Son irreductibles uno a otra: por bien que se diga lo que se ha visto, lo visto no reside jamás en lo que se dice, y por bien que se quiera hacer ver, por medio de imágenes, de metáforas, de comparaciones, lo que se está diciendo, el lugar en el que ellas resplandecen no es el que despliega la vista, sino el que definen las sucesiones de la sintaxis. (p. 27) [cursivas propias]

Retomando esta observación de Foucault donde remarca la infinita dislocación entre lo que se dice y lo que se muestra, y considerando la perspectiva de Aby Warburg y su intento de pensar las imágenes a partir de su incardicación o puesta en relación, en este artículo se propone un modo de trabajo que no subsuma las imágenes a un modelo verbal o semiológico de análisis, sino a un abordaje que tome en cuenta la dimensión del mostrar (Boehm, 2014). Para ello se recurrirá a los estudios vinculados a la Bildwissenschaft, corriente alemana que instituyó nuevos modos de pensar la imaginería desde una mirada multidisciplinar que ha ampliado el terreno hurgado por la Historia del Arte tradicional, bajo la expresión ikonische Wende -giro icónico- (Boehm, 2011). Se hará foco particularmente en el trabajo de Horst Bredekamp (2017) y su teoría de los actos de imagen, que propone dar cuenta de las relaciones entre imagen y cuerpo a partir de una perspectiva que concibe a las mismas como agentes capaces de actuar, y, por lo tanto, como protagonistas de la historia y armas de la política. La noción de acto de imagen se emparenta con los planteos sobre la performatividad del lenguaje desarrollados por Searle (1994) y Austin (1990), a través de la teoría de los actos de habla. Los enunciados performativos son aquellos que generan un efecto en el mundo, ya que por el solo hecho de producirse, instituyen una transformación. Bredekamp retoma aquella tradición, pero introduce un cambio significativo: propone pensar a la imagen no "en el lugar de las palabras sino en el de quien habla" (2017, p.35). En ese sentido, se problematiza sobre el vínculo entre imagen y cuerpo, y se sostiene el supuesto de que hay diferentes tipos de intercambio entre el sujeto (un cuerpo) que mira y la imagen que es mirada. De allí, serán de interés para Bredekamp aquellos retratos cuyas miradas persiguen al espectador y parecen "hablar" en primera persona del singular. En esta teoría se distinguen tres 
tipos de actos de imagen que expresan distintas modalidades de relación entre cuerpo e imagen: esquemático, que da cuenta de aquellas imágenes que sirven de modelos para los cuerpos y por lo tanto, cobran vida o simulan estar vivas, siendo entonces cuerpos que devienen imágenes; sustitutivo, donde cuerpo e imagen se vuelven intercambiables (cuyo modelo ejemplar es la vera icon del rostro de Cristo); y, por último, el intrínseco, donde la imagen se vuelve acto por la potentia de su forma. Se trata, según el autor, del acto de imagen por excelencia. Hay, claro está, una ambivalencia constitutiva, ya que estas imágenes expresan una tensión entre páthos y éthos que no puede resolverse, y de allí su fuerza.

En la elaboración de series de imágenes realizadas para este trabajo se ha encontrado una insistencia de los actos de imagen sustitutivos e intrínsecos, ya que tanto el cuerpo del desaparecido como la forma de su mirada se destacan como valor en las producciones imagineras relevadas en el corpus.

Por otra parte, si bien puede ya parecer evidente, no se sostiene aquí una perspectiva que conciba a los materiales fotográficos como ilustraciones para "explicar" un proceso de la historia contemporánea como el caso de Santiago Maldonado. Por el contrario, el presente trabajo sostiene la tesis de que las fotografías de su rostro que se han replicado a través de redes o bajo la forma de pancartas, o retomado para intervenciones murales o stencils, son definitivamente agentes activos, elementos instituyentes de los acontecimientos históricos y también de las memorias colectivas. No solo Bredekamp funciona como fundamento de esta posición. Se han retomado investigaciones como las de Gamarnik (2020), quien en sus trabajos acerca de la historia del fotoperiodismo en Argentina, plantea que la fotografía es un elemento constituyente de los acontecimientos históricos. La investigadora destaca que hay momentos donde una determinada imagen se constituye en un acontecimiento visual. Sostiene además que es fundamental dar cuenta del modo en que los movimientos políticos construyen y piensan sus estrategias visuales, como lo ha indicado con respecto a las Madres de Plaza de Mayo (Gamarnik, 2010). Por otra parte, se ha tomado en cuenta el papel de la fotografía como artefacto memorial - que no se agota en la técnica- que ha logrado colocar lo indicial en un lugar de privilegio para el procesamiento de acontecimientos traumáticos mediante la memoria colectiva. Sobre esto indica Natalia Fortuny:

De hecho, las fotografías comparten en su mayoría las características pensadas para los testimonios verbales: suponen una primera persona -una perspectiva: la mirada de un ojo que establece un punto de vista particular-; hay en ellas tensión entre lo singular y lo social, y hay por supuesto en ambas ambigüedades, cosas no dichas, reconstrucción, silencios, incompletitud. En el lugar de intercambio entre lo individual y lo colectivo, las fotografías como testimonios visuales se ubican a medio camino entre una historia exterior y los esfuerzos siempre incompletos de una memoria. (Fortuny, 2014, p. 134)

Las imágenes en su dimensión productiva son, entonces, la principal apuesta metodológica y teórica que funciona como guía para el abordaje de series que se han elaborado para este texto.

Por último, no puede olvidarse que el despliege de la iconografía sobre Santiago Maldonado se produce y circula en el marco de un escenario de conflicto donde fue la militancia insistente en diversos terrenos -digitales y también físicos- la que hizo posible que la desaparición y luego la muerte sean reconocidas como un tema 
público inscripto en una problemática previa, tal como ha ocurrido con otras muertes de relevancia mediática (Gayol y Kessler, 2018). Esto habilita a pensar el despliegue de la dimensión estética de la política en un sentido de disputa por lo sensible, e implica problematizar sobre los modos en que esa dimensión entra en juego en una comunidad que está partida por un reparto desigual de los espacios y las temporalidades. Se trata de un litigio por la distribución de aquello que puede o no puede ser visto, de lo que puede decirse y lo que no (Rancière, 2008). ${ }^{4}$ Esto remite primero a la circunscripción del caso de Santiago Maldonado y el papel que las imágenes han tenido como instituyentes de un problema a ser tratado públicamente y también de los ataques y censuras practicados por quienes se negaron a reconocer allí a una víctima de la violencia estatal, que da cuenta de una historia de represiones y desapariciones.

\section{El caso}

Santiago Maldonado no era orgánico a ningún espacio partidario y se definía, aseguran su hermano Sergio Maldonado y quienes convivieron con él, como un militante anarquista y activista de la causa mapuche. ${ }^{5}$ La última vez que fue visto con vida se encontraba en el corte de ruta, cuando Gendarmería Nacional Argentina reprimió a quienes protestaban en la zona. Los gendarmes desalojaron el camino e ingresaron a la comunidad mapuche Pu Lof en Resistencia y persiguieron a los manifestantes hasta la orilla del río. La noticia de la desaparición en el contexto de una represión comenzó a circular por las plataformas Facebook y Twitter, gracias a la información que aportaron medios de comunicación alternativos y regionales. Luego se sumaron instituciones como el Centro de Estudios Legales y Sociales, el canal televisivo $C 5 N$, y diarios como Página 12, Infobae, y La Izquierda Diario.

Fue recién cuatro días después de la desaparición que la noticia cobró notoriedad en redes sociales bajo hashtags como \#DondeEstaSantiagoMaldonado o \#SantiagoMaldonado. El 11 de agosto se convocó a una marcha multitudinaria a Plaza de Mayo mientras el tema ya dominaba la agenda nacional, con un impacto significativo a nivel internacional. Diversas imágenes de Santiago Maldonado circularon masivamente por diferentes emplazamientos mediáticos y no mediáticos, evocando, como veremos a continuación, la tradición iconográfica referida a los desaparecidos y asesinados tanto en dictadura como en democracia. A pesar de que Maldonado fue encontrado sin vida el 17 de octubre de ese mismo año, las intervenciones que denunciaron la violencia estatal no cesaron de producirse. El 25 de noviembre, día del entierro de su cuerpo, el grupo Albatros de la Prefectura Naval realizó un operativo de desalojo sobre la comunidad Lafken Winkul Mapu. Durante la represión con balas de goma y plomo, resultó asesinado Rafael Nahuel, un joven mapuche de 22 años que participaba de dicho espacio. Su muerte, como la desaparición y hallazgo del cuerpo de Santiago Maldonado, fue transformada en un acontecimiento público, impulsado nuevamente en las redes sociales, pero sin el mismo impacto. A propósito de esto Gayol y Kessler (2018) señalaron que posiblemente la razón por la cual el caso Maldonado generó una identificación 
con gran parte de la población, radicaba en su condición de "joven blanco de clase media" 6 .

\section{La lucha por la memoria y la performatividad de las imágenes}

La memoria es un proceso dinámico atravesado por conflictos, una configuración de recuerdos que actúan en el presente, aun cuando se trate de una disputa por rememorar un pasado. Se trata, como indica Halbwachs (2004), de un proceso social, ya que la memoria individual se entrelaza con la memoria colectiva, la cual desenvuelve en una comunidad afectiva. En ese proceso hay diferentes sectores sociales que luchan por establecer su propias imágenes y relatos acerca de acontecimientos históricos. Las memorias referidas a masacres o casos de violencias son un terreno habitual de este tipo de construcciones y conflictos.

Santiago Maldonado desapareció luego de haber sido visto en el marco de un operativo de Gendarmería Nacional que terminó con tres detenidos. El hecho fue catalogado por diversos grupos activistas como una desaparición ${ }^{7}$ cuya responsabilidad recaía en las fuerzas de seguridad y los funcionarios estatales. Uno de los aspectos distintivos de la controversia que generó este suceso fue la posición tomada por el gobierno nacional encarnado por la alianza Cambiemos, que se definió por una explícita y férrea defensa de las fuerzas de seguridad, como lo indicaron diversas declaraciones de la ministra de seguridad de la nación Patricia Bullrich. ${ }^{8}$ Cabe destacar además, que Cambiemos ya había hecho pública su postura sobre la cuestión de los desaparecidos y las políticas de Derechos Humanos. Durante la campaña para su candidatura, Mauricio Macri había indicado que la cooperativa Sueños Compartidos y otras acciones no especificadas vinculadas a la Asociación Madres de Plaza de Mayo eran un "curro", 9 mientras que ya como presidente calificó a la última dictadura militar como "guerra sucia" e indicó que no le interesaba discutir la cantidad de desaparecidos, ya que era una "discusión sin sentido". ${ }^{10}$ A su vez, funcionarios como Juan Gómez Centurión (titular de la Aduana) y Darío Lopérfido (Ministro de Cultura de la ciudad de Buenos Aires) cuestionaron la cifra de treinta mil desaparecidos y relativizaron la responsabilidad del Estado y sus fuerzas armadas en la violación de los derechos humanos. ${ }^{11}$ En el comienzo de la gestión macrista, la Corte Suprema de Justicia habilitó la posibilidad de que a Luis Muiña, declarado culpable de delitos de lesa humanidad, se le aplicara la compensación popularmente llamada "dos por uno", que determina que a las personas detenidas por más de dos años en prisión preventiva se les compute cada año de prisión como dos años, reduciendo así el tiempo transcurrrido de condena. El 10 de mayo, una semana después de conocido el fallo, una masiva movilización impulsada por organismos militantes por los derechos humanos, bajo la consigna "Nunca más privilegios a los criminales de lesa humanidad", rechazó el fallo de la Corte. Un año después, la decisión fue revertida por ella misma.

En ese marco, el reclamo por la aparición de Santiago Maldonado se transformó en un asunto público inscripto en una serie que se vinculó a los casos de desapariciones llevadas a cabo por las fuerzas estatales en la última dictadura militar y también a aquellas perpetradas en democracia, marcando un conflicto pre-existente no resuelto. Por ello la causa Maldonado se transformó en 
el principal eje de disputa entre gran parte de la oposición y el gobierno. Sectores ligados a la izquierda y al peronismo, entre los que se encontraban grupos de fotoperiodistas y activismo artístico, llevaron a cabo múltiples movilizaciones y acciones colectivas tanto en redes como en las calles, que fueron ocupando gradualmente la agenda informativa. Las imágenes que circularon fueron operando, al decir de Rousso (citado en Pollak, 2006), como encuadramiento de la memoria colectiva y como elemento de remisión hacia esa problemática ya existente. Fotografías digitales o impresas en pancartas del rostro de Santiago Maldonado, murales, e incluso máscaras, hicieron su aparición en el espacio público para politizar la desaparición y transformarla en un tema periodístico. La más compartida y la que comenzó a circular cuando la noticia de su desaparición constituía apenas un par de posteos en Facebook o tweets, fue una auto foto llamada popularmente selfie- que Santiago Maldonado envió por su celular días previos al hecho (Figura 1). ${ }^{12}$

Figura 1. Autoretrato de Santiago Maldonado de circulación pública.

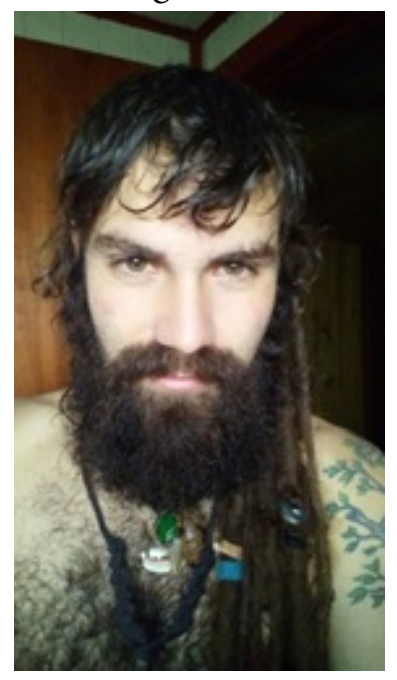

Fuente: "Tiene que aparecer" (06 de agosto de 2017), carta de Sergio Maldonado publicada en La Poderosa. Recuperado en: https://lapoderosa.org.ar/2017/08/tiene-que-aparecer/

Figura 2. Fotografía recortada y con filtro, con amplia circulación pública.

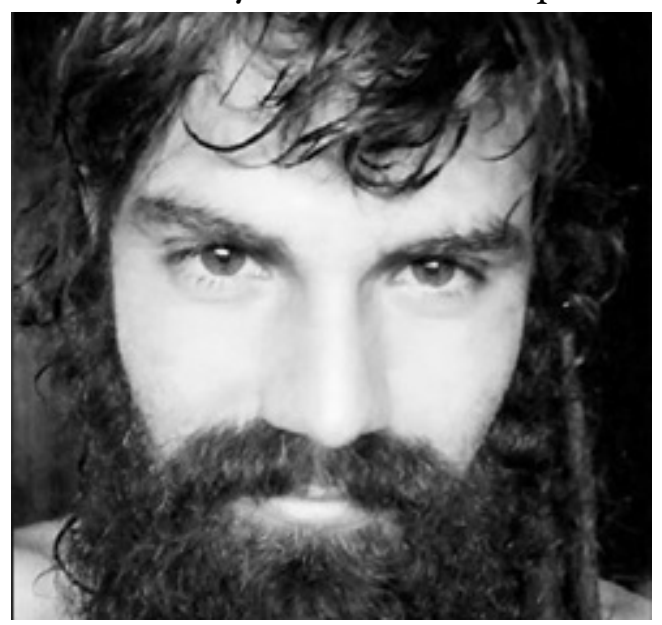

Fuente: Los famosos y sus mensajes tras el reconocmiento del cadáver de Santiago Maldonado (20 de octubre de 2017) en Primicias Ya. Recuperado en: https://www.primiciasya.com/los-famosos-y-sus-mensajes-el-reconocimiento-del-cadaver-santiago-maldonado-n 1491863 
El 28 de agosto de 2017, el Movimiento Argentino de Fotógrafxs Independientes Autoconvocadxs (M.A.F.I.A) ${ }^{13}$ comunicó a través de sus redes sociales la propuesta de realizar una acción colectiva denominada Dónde está Santiago Maldonado, retomando una de las consignas-preguntas centrales en el reclamo de las Madres y Abuelas de Plaza de Mayo. La tarea consistía en intervenir el espacio público con una fotografía tomada por este mismo grupo el 11 de agosto de 2017, donde puede verse a una mujer marchando y sosteniendo el retrato de Santiago Maldonado, en la primera gran marcha a Plaza de Mayo en reclamo por su aparición (Figura 3). El grupo indicaba en su convocatoria: "La invitación es que todxs juntxs, por todas partes de nuestro país y del mundo, intervengamos las calles, las paredes, las plazas, las rutas, los caminos, todo el espacio público, con esta foto" (M.A.F.I.A, 2017). Los organizadores crearon un Tumblr con el nombre de la acción, donde quien deseaba formar parte podía descargar la fotografía en diferentes tamaños, para luego imprimirla y pegarla en cualquier superficie, retomando una práctica habitual en el activismo artístico efectuada en casos como el de Darío Santillán y Maximiliano Kosteki o el reclamo por la aparición de Jorge Julio López. ${ }^{14}$

Aquel día la convocatoria fue masiva y podían verse pancartas con la consigna que impulsaba la marcha y otras que poseen una larga tradición en otros reclamos ligados a los derechos humanos. Una de ellas, además de la pregunta ya mencionada, fue "Aparición con vida", que acompañaba miles de carteles con la imagen del rostro de Santiago. Aquella fotografía del rostro, la primera que comenzó a circular en esos primeros días de agosto, se había viralizado días antes de la movilización por redes sociales, para reclamar por la aparición del joven, junto con mensajes que habían logrado ser tendencia en Twitter. Esos contenidos, una vez convertidos en tendencia, lograron incidir y forzar a la prensa a retomar el caso en sus agendas. ${ }^{15} \mathrm{La}$ elección de esa imagen por parte de M.A.F.I.A reconocía implícitamente una tradición notoria: las marchas de las Madres y Abuelas de Plaza de Mayo, junto con jóvenes militantes y activistas de los movimientos por los derechos humanos, que portaban imágenes de los rostros de sus familiares desaparecidos durante la última dictadura cívico-militar. Cabe destacar que aquél fue un día de intensa lluvia y por esa razón el retrato de Maldonado que sostiene la persona fotografiada se encuentra en un folio.

Dicha imagen (Figura 3) recuerda una serie amplia de fotografías donde pueden verse a las Madres de Plaza de Mayo sosteniendo las fotos de sus familiares desaparecidos. En particular, puede citarse un conjunto reconocido de ellas tomadas el 28 de abril de 1983 por Daniel García en una manifestación y bajo una lluvia intensa (Figuras 4). Por otra parte, la imagen propuesta por el grupo para intervenir las ciudades y el territorio digital reúne las características de una meta-imagen, ya que se trata de una fotografía que no nos presenta solo a una mujer marchando sino que también contiene otra imagen, la del rostro de Santiago Maldonado. Una meta-imagen implica la institución de una capacidad auto-reflexiva, pues se trata del "lugar donde las imágenes se revelan y se 'conocen', donde reflexionan sobre las intersecciones entre la visualidad, el lenguaje y la similitud, donde especulan y teorizan sobre su propia naturaleza e historia." (Mitchell, 2009, p.77). 
Figura 3. (M.A.F.I.A, 2017). Marcha en reclamo por la aparición con vida de Santiago Maldonado, 11 de agosto de 2017, Ciudad Autónoma de Buenos Aires. Imagen propuesta para intervenir el espacio público.

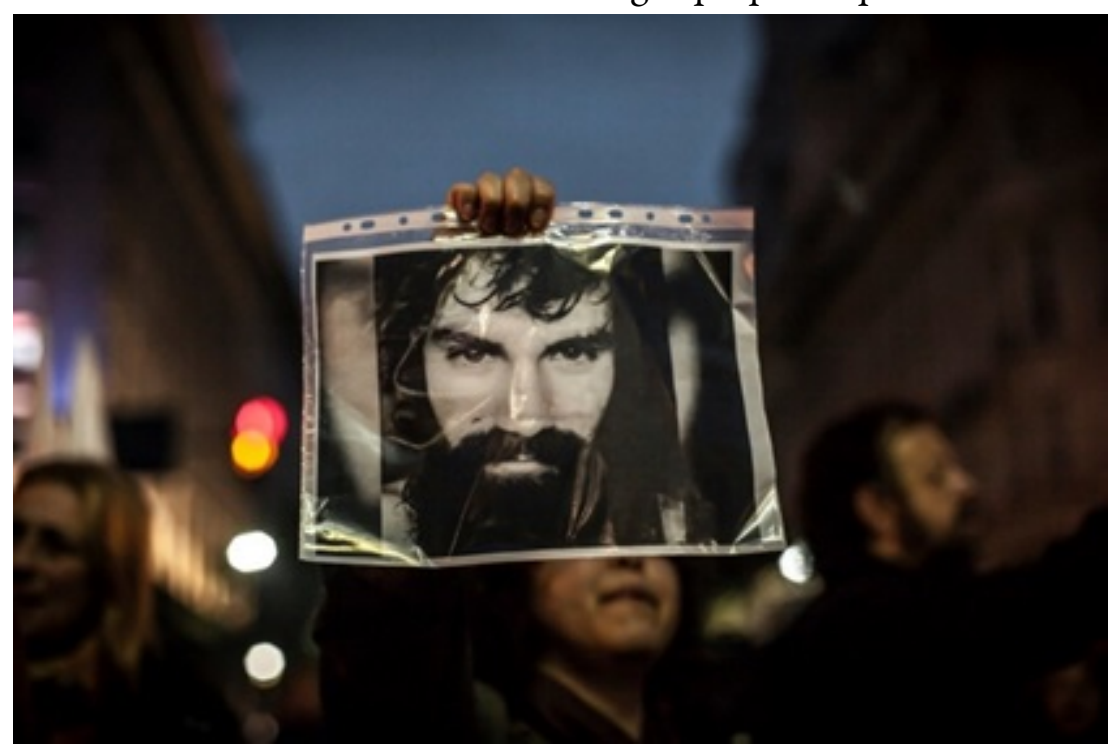

Fuente: https://www.facebook.com/holamafia/photos/a.1461689027252606/1461690480585794

Figura 4. Marcha de las Madres de Plaza de Mayo, donde llevan las pancartas que exhiben los rostros de sus hijos desparecidos. Buenos Aires, 28 de abril de 1983.

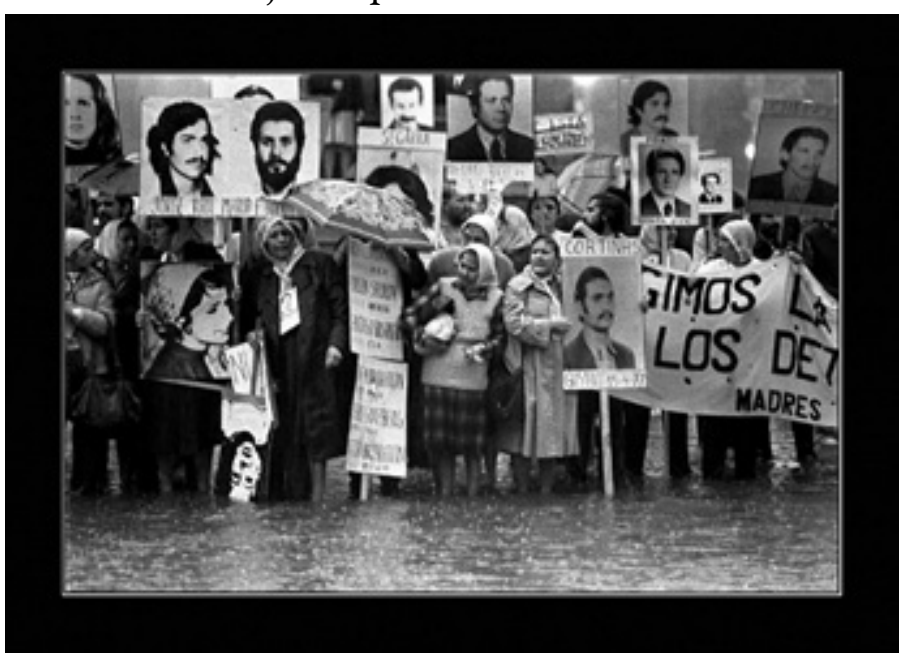

Fuente: Fotografía de Daniel García. Versión digital extraída de http://www.archivosenuso.org/ddhh-archivo/daniel-garcia

Esta elección y relación con las fotografías citadas, como se ha dicho, no es explicitada por parte del grupo activista, ya que forma parte de imaginarios instituidos (Castoriadis, 2007) que se vinculan con una práctica -marchar sosteniendo una fotografía- y un tipo de imagen específica -la del rostro de una persona desaparecida- ligada a los reclamos por los derechos humanos. De acuerdo con da Silva Catela (2009), desde que las Madres comenzaron a buscar a sus familiares desaparecidos mostrando las fotografías de sus caras -que en general eran carnets de identidad- en comisarías, estas se volvieron centrales como prueba de la existencia de la persona desaparecida, ya que fueron cobrando centralidad en las distintas acciones visuales de lo que luego será el movimiento Madres de Plaza de Mayo. Indica Longoni (2010) que alrededor de 1978, ellas comenzaron a manifestarse portando esas mismas fotografías en pancartas, usando su cuerpo 
como soporte. Inventaron así una perfomance que se ha expandido incluso a otros países del continente en ese acto de sostener las fotografías de sus familiares $\left(\right.$ Noble, 2008) ${ }^{16}$. Como afirma da Silva Catela, esta puesta en imagen de la desaparición a través de rostros se instaló fuertemente en la iconografía de protesta:

Una foto en blanco y negro utilizada en una marcha, portada sobre el cuerpo de una Madre, colgada en una plaza, estampada en una bandera argentina, raramente reciba la pregunta de “'quiénes son?” " “qué significa?”. Hay un sustrato cultural y político, compartido y establecido entre la memoria de los desparecidos, su recuerdo, y las fotografías en blanco y negro (da Silva Catela, 2009, p. 338)

Desde ese momento y hasta la actualidad, estas se convirtieron en una imagensíntoma (Didi-Huberman, 2009) de la desaparición por parte del Estado, es decir, una figura que viene a indicar aquello que insiste para existir, lo dislocado que no pertenece al tiempo de la historia sino al de la memoria inconsciente de las imágenes, del tiempo de lo fantasmático. ${ }^{17}$

Esa preminencia de las imágenes como elemento y acción de protesta y de memoria -ya que no solo recuerdan o inscriben determinados casos y sus víctimas en una trama- se explica por la capacidad de agenciamiento que las mismas poseen, ya que en tanto que actos de imagen constituyen memorias, contribuyen a pensar la historia e intervienen en el campo de la política como agentes:

La suposición de que las imágenes tienen que ser "verdaderas" en el sentido de un documento auténtico, está unida a este mensaje activador, que responde a la necesidad de encontrarse, con ayuda de las imágenes, con una persona o ser parte de una acción. En tanto las imágenes son consideradas como agentes vivos, generadores de hechos, estos principios son también efectivos en el campo político. Esta es la razón por la cual es difícil distinguir tajantemente entre historia e historia de las imágenes. Las imágenes están en el mundo de los acontecimientos en una relación que es a la vez de reacción y de formación. No sólo repiten la historia pasivamente sino que son capaces, como cualquier otro acto u orden de actuar, de acuñarla: como acto de imagen, crea hechos, mientras instaura imágenes en el mundo. (Bredekamp, 2004, p. 29) [cursivas propias]

Este "mensaje activador" habilita a considerar a las imágenes como productoras de afectos. Desde otra perspectiva, observa Pollak un aspecto similar al afirmar que el cine es un gran soporte para lograr ese encuadramiento de la memoria, ya que "se dirige no sólo a las capacidades cognitivas sino que capta las emociones” (Pollak, 2006, p. 28). Esta tesis ya fue también pensada en profundidad por el historiador del arte Aby Warburg (2014) -autor central para el enfoque de Bredekamp-, al atender en sus investigaciones a lo que llamó Pathosformel, cuya traducción sería la de fórmula emotiva o del páthos: imágenes que por su gran fuerza emotiva hace que permanezcan como engramas en la memoria. Hay para Warburg una vida que insiste, una fuerza vital que puja por existir, y eso es lo que este pensador intentó mostrar a partir de ese montaje en el espacio que no casualmente nombró como Atlas Mnemosyne. De acuerdo con Horst Bredekamp (2017) las Pathosformeln son imágenes que por la fuerza intrínseca de su forma son capaces de actuar, como si fueran agentes vivos. De allí que Warburg se refiera al concepto de Nachleben -cuya traducción podría ser la de pervivencia- para abordar ciertas imágenes de la antigüedad. 
La fotografía de Santiago Maldonado propuesta para intervenir el espacio público reúne todas las características de una imagen productora de afectos, en especial en la zona de la mirada del retratado. El rostro fotografiado, como ha dicho Walter Benjamin, se posiciona como la última trinchera del valor cultual que no cede a la reproductibilidad técnica:

En el culto de la memoria de los seres queridos lejanos o muertos la imagen tiene su último refugio. En la expresión fugaz de un rostro humano de las primeras fotografías el aura hace señas por última vez. Esto es lo que constituye su melancolía y con nada comparable belleza (Benjamin, 2019, p. 97). ${ }^{18}$

El efecto de la mirada es entendido aquí como una Pathosformel que posee una larga historia en la iconografía política y religiosa, que va desde las imagines agentes (Bredekamp 2017), hasta carteles de reclutamiento para la Primera Guerra Mundial como la famosa imagen de Lord Kitchener (Figura 5) estudiada por Carlo Ginzburg (2001), que hunde sus raíces en la iconografía religiosa (Figura 6).

Figura 5. Cartel de reclutamiento realizado por Alfred Leet. Publicado por primera vez el 05 de septiembre de 1914 en el semanario London Opinion, Londres.

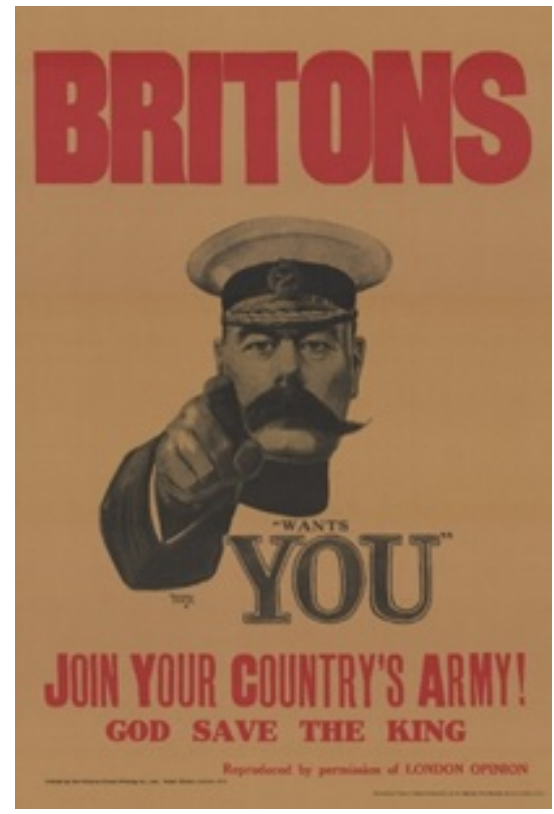

Fuente: Imperial War Museumshttps://www.iwm.org.uk/learning/resources/first-world-war-recruitment-posters 
Figura 6. Pintura de Dirk Bouts, Christus, Salvator Mundi (Vera effigies), 1464.

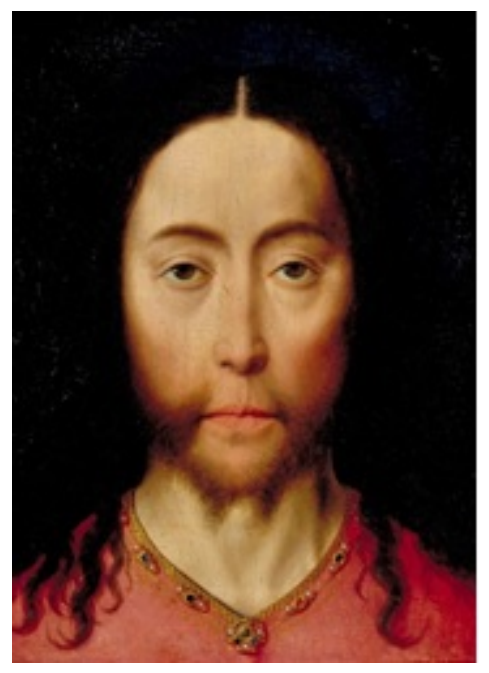

Fuente: Museo Boijmans Van Beuningen, Rotterdam.

En el caso de Maldonado, dicha Pathosformel, en tanto que acto de imagen, renace como insistencia y llamado para "no olvidar a Santiago", y fuerza un interrogante que cuestiona un orden político. Esto puede evidenciarse en una acción similar a la de M.A.F.I.A, pero convocada el 24 de julio de 2018 casi un año después de la desaparición- que bajo el nombre de "Santiago, tu mirada nos mira", ${ }^{19}$ recorta de la fotografía tan solo la mirada. Del mismo modo en que Ginzburg, señala esa interpelación o llamado a los reclutas, aquí opera una interpelación similar pero para una causa radicalmente diferente, e incluso opuesta, pero funciona de modo similar ya que las Pathosformeln pueden ser utilizadas en sentidos muy diversos e incluso contrarios, tal como dice el historador italiano: "Warburg llegó a plantear que la fórmula -el gesto emocional- era una fuerza neutral, abierta a diferentes interpretaciones, incluso a interpretaciones opuestas" (Ginzburg, 2001, p.12).

La intención del "llamado" se hace explícita en la convocatoria elaborada por el grupo activista que invitaba a intervenir el espacio público y digital con la imagen de la mirada:

"Santiago, tu mirada nos mira" es un llamado a personas, grupos, colectivas, organizaciones populares a inundar las calles de intervenciones artísticas que potencien el mensaje de lucha de Santiago, de las comunidades mapuche y de todos los sectores organizados que resisten el avance represivo del gobierno.

En sus ojos se refracta caleidoscópica nuestra resistencia al olvido: queremos multiplicarlos, para encender las luchas, porque Santiago, el brujo, el lechuga, un pibe solidario se convirtió en compañero de todxs.

Estamos proponiendo acciones como replicar retratos, hacer gigantografías o producir murales-collages, para interpelar desde el ardor de su mirada con una pregunta necesaria ¿La presencia sistemática y creciente de crímenes de estado lxs fusiladxs y desaparecidxs de la pseudodemocracia- nos va a detener o nos va a motorizar? Seremos grito, cuerpx y abrazo. ${ }^{20}$ 
Figura 7. Intervención del colectivo Santiago, tu mirada nos mira en Santa Fe.

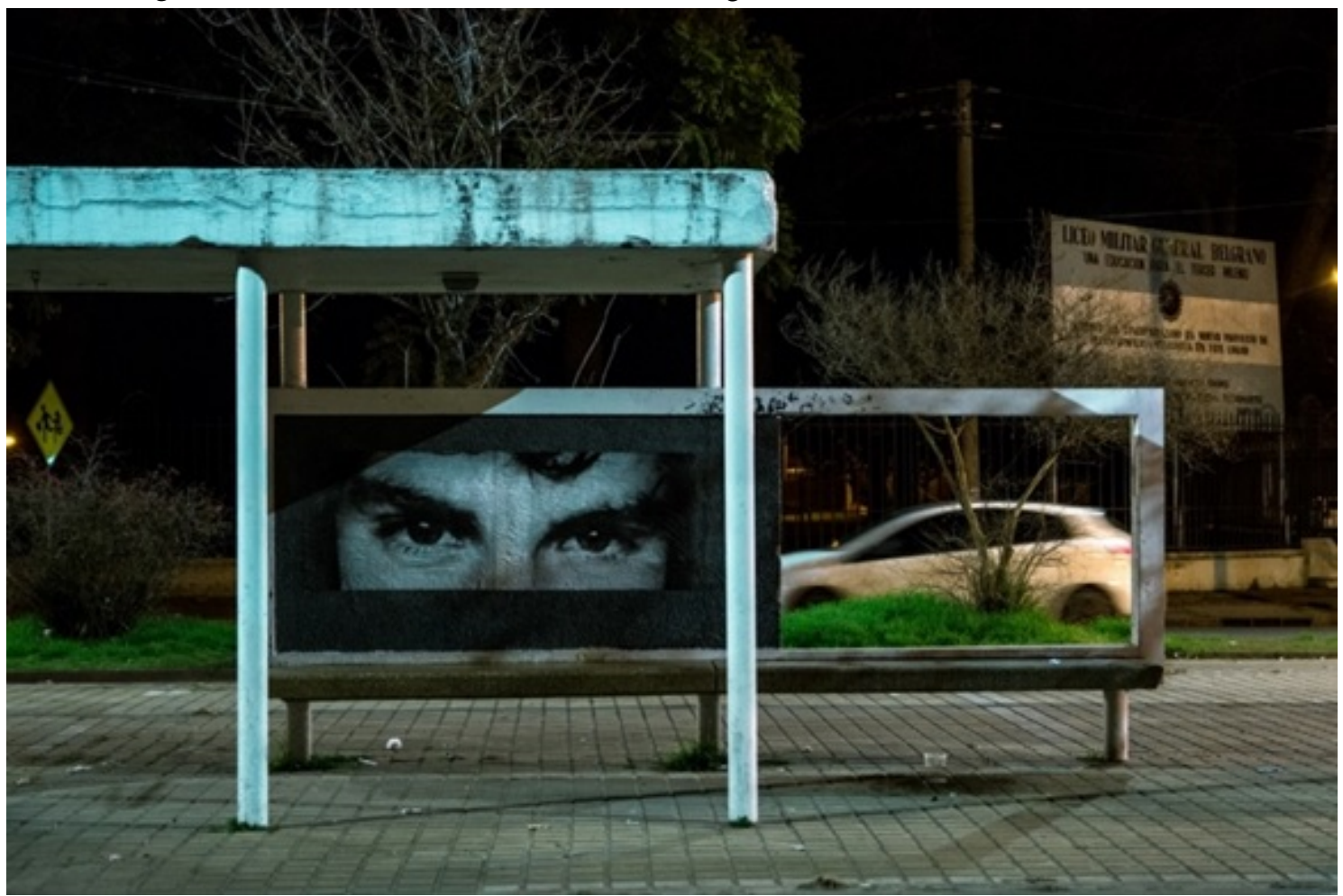

Fuente: Imagen publicada en la nota La mirada de Santiago en Santa Fe ( 1 de agosto de 2018), Pausa, http://www.pausa.com.ar/2018/08/la-mirada-de-santiago-en-santa-fe/

Pero no todo es afecto en Warburg, ya que su propuesta también implica concebir a las imágenes como espacios para el pensamiento (Denkraum), ${ }^{21}$ en tanto que producen una implicancia en el espectador al apelar al páthos, pero a su vez las imágenes funcionan como un conjuro frente a esa misma afección patética, generando un distanciamiento que permite elaborar un duelo. Implicación y distancia, ese movimiento de tensión, ambivalente, es el que caracteriza al proceso de la memoria y sus imágenes. Pero algo que los enfoques warburgianos clásicos han trabajado en menor medida es la disputa por la que es atravesada esa memoria construida o performada por las imágenes. Y es que las fotografías (sobre todo las fotografías) y otros dispositivos visuales producidos por el activismo artístico vinculado al caso no solo invitan a vincular una desaparición con otra, un caso con otro, sino que también son "armas" de intervención públicas que querellan y señalan un antagonismo.

Como se observa en las imágenes que siguen (Figuras 8 y 9), la constelación de rostros va de Santiago Maldonado a Jorge Julio López y Luciano Arruga, implicando en el señalamiento de los responsables políticos también al kirchnerismo, pues los casos de los dos últimos sucedieron bajo las presidencias de Néstor Kirchner y Cristina Fernández. En la fotografía de Javier Valente, tomada el 19 de octubre de 2017 en una movilización articulada con la habitual ronda de las Madres de Plaza de Mayo, Nora Cortiñas acompaña el reclamo por la aparición con vida de Santiago Maldonado con el puño en alto, otro gesto insistente y de lucha propio de la iconografía política. Mientras, puede verse a una manifestante sostener un dibujo de Julio López portando una remera con el rostro de Luciano Arruga mientras alza una imagen de Maldonado, figurando 
una vez más ese gesto de portar las imágenes de rostros. Lo característico aquí son esas tres figuras desaparecidas articuladas en una misma imagen.

Figura 8. Ronda de las Madres de Plaza de Mayo, 19 de octubre de 2017, Ciudad de Buenos Aires.

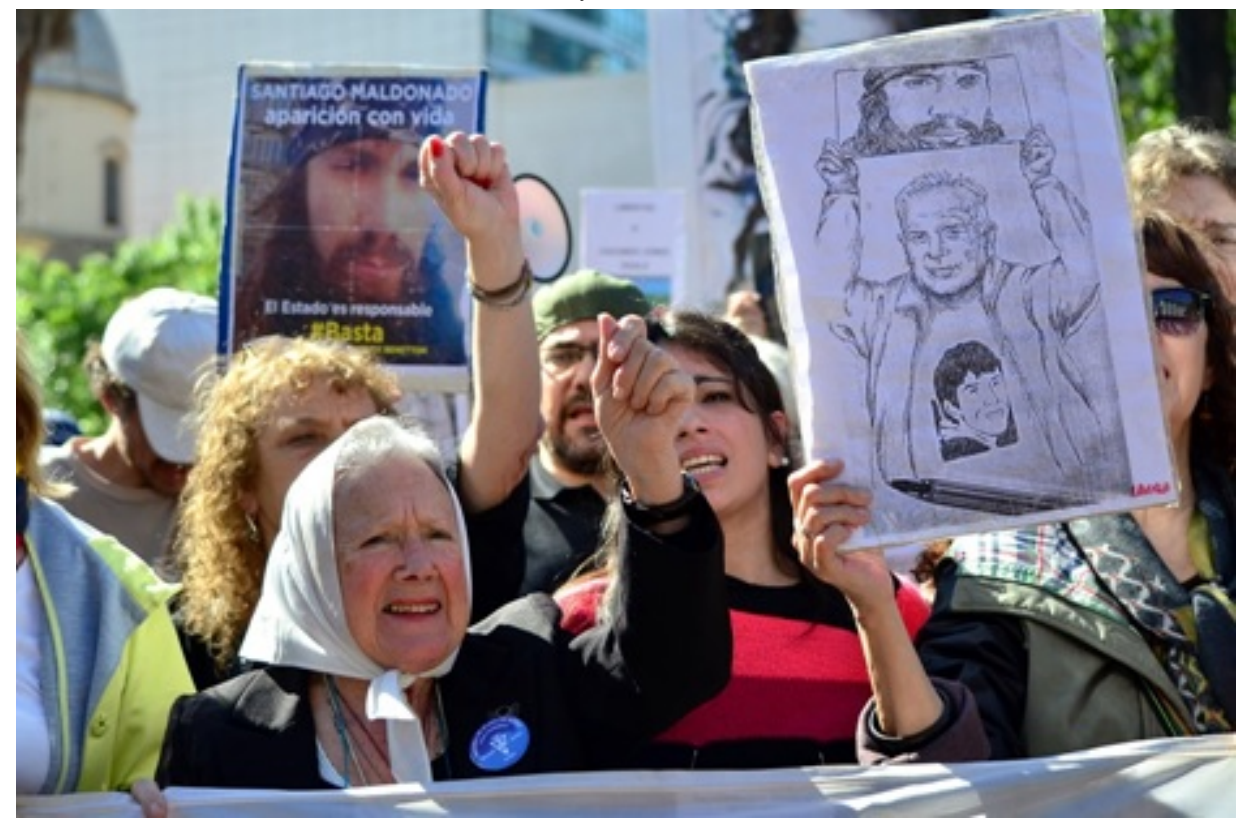

Fuente: Fotografía de Javier Valente publicada en la nota Una multitud acompañó la marcha de las Madres y el acto por Santiago Maldonado (20 de octubre de 2017), Red Eco Alternativo. Recuperada en: http://www.redeco.com.ar/nacion al/ddhh/22442-una-multitud-acompa\%C3\%B1\%C3\%B3-la-marcha-de-las-madres-y-el-acto-por-santiago-maldonado.

Otro dibujo similar que circuló en plataformas y portales de noticias digitales fue el de la silueta característica de López, muy habitual en los reclamos por su aparición. Portando su gorro, sostiene la misma imagen del rostro de Maldonado. Aparece en este punto la articulación entre las dos matrices de representación características de los desaparecidos: retratos fotográficos y siluetas (Longoni, 2010). Y es que aquella acción llevada a cabo el 21 de septiembre de 1983 denominada Siluetazo fue un acontecimiento que produjo una iconografía propia que todavía hoy sigue vigente. Como observan Burucúa y Kwiatkowski (2014), inspirándose, pero ampliando el concepto de Pathosformel warburgiano, la silueta devino una fórmula de representación de masacres.

Estas dos matrices también aparecen conjugadas en una imagen realizada por el grupo activista Iconoclasistas (Figura 10), donde el rostro de Santiago Maldonado se condensa con el mapa de Argentina, indicando que se trata de una desaparición que evidencia un problema público que atraviesa todo nuestro territorio. Por otra parte, teniendo en cuenta que el hecho tuvo lugar en medio de un conflicto por la tierra entre el Estado nacional y el pueblo Mapuche, se activa no solo una remisión a los desparecidos sino también a la larga lucha de los pueblos indígenas por sus territorios. Puede observarse en esa remisión el vínculo indicado por da Silva Catela (2019) entre memorias cortas -las relacionadas con la dictadura y la desaparición- y memorias largas -la lucha de los pueblos originarios-. En ese sentido la antropóloga indica acertadamente:

En ese territorio de inscripción de la desaparición/aparición/muerte de Santiago Maldonado se activaron memorias largas, las de las comunidades de los pueblos originarios y las mapuches específicamente, violencias "tatuadas" e inscriptas en sus cuerpos por años y años de represión, racismo y exclusión. Y las memorias cortas 
que remiten al proceso del terrorismo de Estado y las representaciones y experiencias frente a la desaparición de personas, a los "desaparecidos".

Estos dos momentos y formas de memoria confluyeron en el cuerpo y con el cuerpo de Santiago. Un cuerpo que pasó a cargar con la lucha y los muertos por la tierra de las comunidades indígenas y que volvió a visibilizar el drama nacional de los desaparecidos (p. 40).

Se destaca que del rostro se encuentran ausentes los ojos y la boca, pero aun así su figura se torna reconocible por la barba que funciona en contraste con la silueta rostrificada. ${ }^{22}$ Esta pieza da por hecho que todos conocemos el rostro de Maldonado debido a su reiterada circulación por el espacio público y los medios de comunicación. Por último, se observa que la barba extendida ocupa gran parte de la imagen del mapa. La vinculación entre esta característica rostritaria y la militancia política tiene una extensa historia en la iconografía política y religiosa de héroes y mártires, remitiéndonos a casos muy conocidos como el de Ernesto "Che" Guevara, Camilo Cienfuegos, Fidel Castro, y Cristo, donde se resalta aún con más notoriedad un éthos heroico.

Figura 9. Dibujo de Noelia Gaillardou.

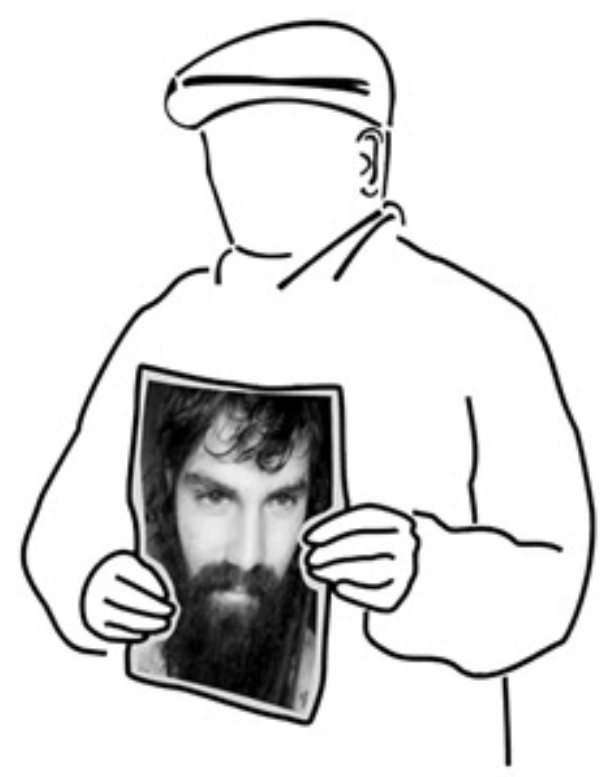

Fuente: publicado en la nota Santiago Maldonado y los que responden en Facebook (28 de agosto de 2017) Cosecha Roja, recuperada en ${ }^{23}$ : http://cosecharoja.org/santiago-maldonado-y-los-que-responden-en-facebook/ 
Figura 10. Imagen de Iconoclasistas publicada el 29 de agosto de 2017 en Facebook

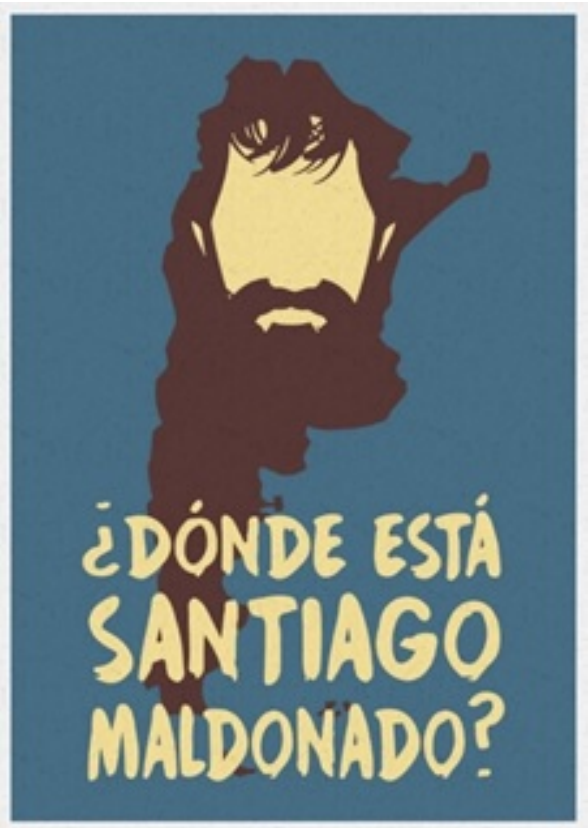

Fuente: https://www.facebook.com/iconoclasistas/photos/1424702127613149

Las imágenes de rostros también ocuparon un lugar en el Espacio para la Memoria y para la Promoción y Defensa de los Derechos Humanos, donde habitó la figura de Santiago junto a las fotografías de otros desaparecidos. En una de las entradas al patio del predio la agrupación H.I.J.O.S. colocó una bandera acusando directamente a la ministra de Seguridad Patricia Bullrich, a Pablo Noceti, su jefe de gabinete y quien dirigía el operativo donde Maldonado fue visto por última vez, y a la propia Gendarmería. ${ }^{24} \mathrm{Al}$ igual que la pieza de Iconoclasistas, el rostro se articula con la pregunta ¿Dónde está Santiago Maldonado?, una interpelación directa al Estado y que, insistimos, deviene una pregunta-consigna que lleva todo el peso de la tradición de lucha de las Madres y Abuelas y los movimientos de derechos humanos, quienes han venido preguntando insistentemente en cada movilización “iQue nos digan dónde están los desaparecidos!”. 
Figura 11. Bandera de H.I.J.O.S. colgada en el marco del Seminario

Internacional Políticas de la Memoria. 30 de septiembre de 2017.

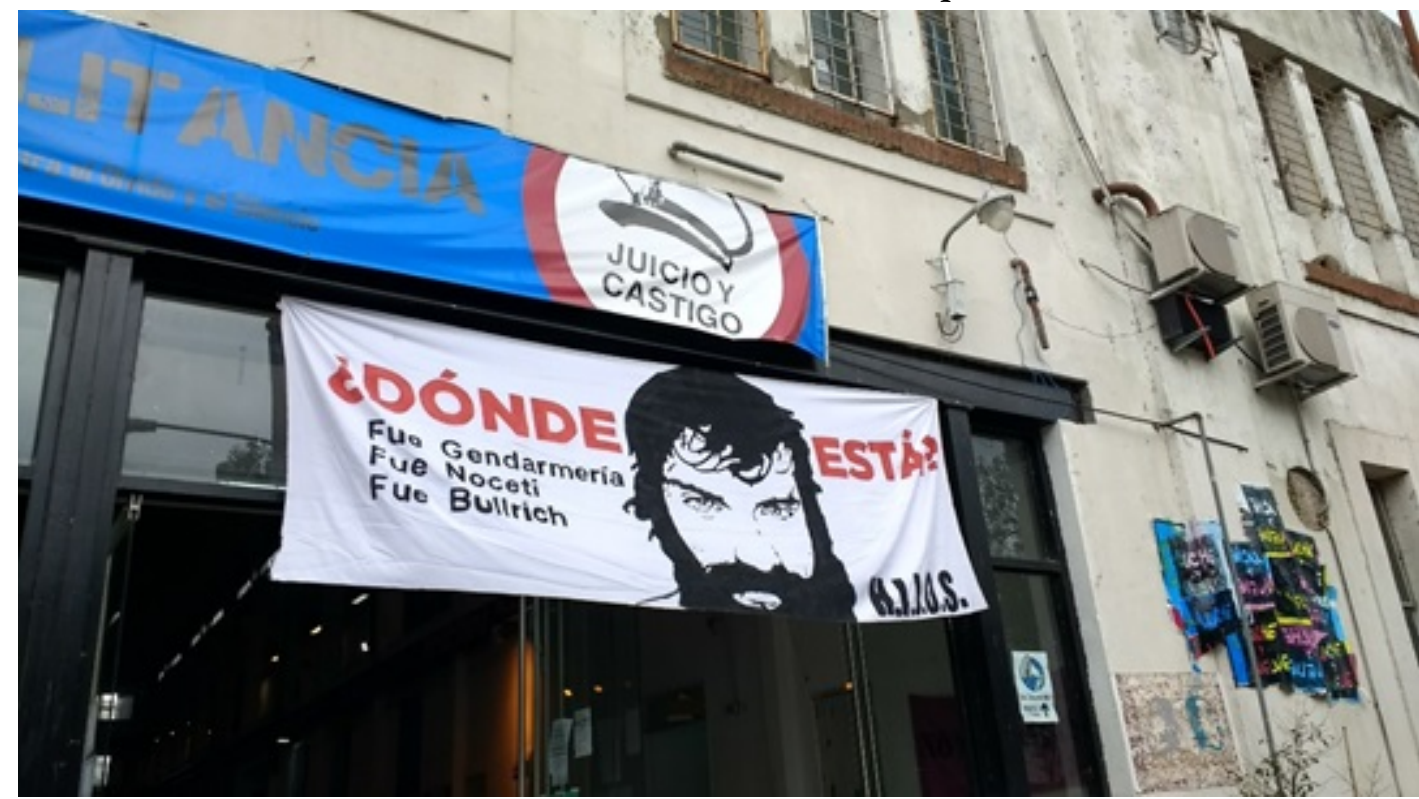

Fuente: Fotografía de autoría propia.

\section{Iconoclasia, censuras y ataques mediante imágenes}

Durante el tiempo en que el caso de Santiago Maldonado se mantuvo como uno de los principales temas de discusión política, y las acciones de protesta y visibilización se fueron expandiendo en las calles, en las plataformas digitales y también en espacios institucionales como la escuela y otras dependencias del Estado, existieron también acciones iconoclastas frente a las imágenes ya mencionadas, así como censuras institucionales o cuestionamientos por parte de funcionarios a cualquiera que aludiera al caso. En el ámbito educativo se llevó a cabo una intensa discusión pública sobre si debía trabajarse o mencionarse el caso en las aulas. ${ }^{26}$ La Confederación de Trabajadores de la Educación de la República Argentina (en adelante, CTERA) lanzó para el Día internacional del detenido desaparecido (el 30 de agosto de 2017), una campaña nacional de adhesión al pedido de aparición con vida. Se distribuyó material para ser trabajado en las clases y se difundieron imágenes de docentes y estudiantes en las escuelas portando pancartas con el rostro de Maldonado, al igual que en las diversas acciones ya señaladas. 
Figura 12. Fotografía publicada por CTERA en su sitio web en el marco de la campaña nacional “¿Dónde está Santiago Maldonado?” (30 de agosto de 2017).

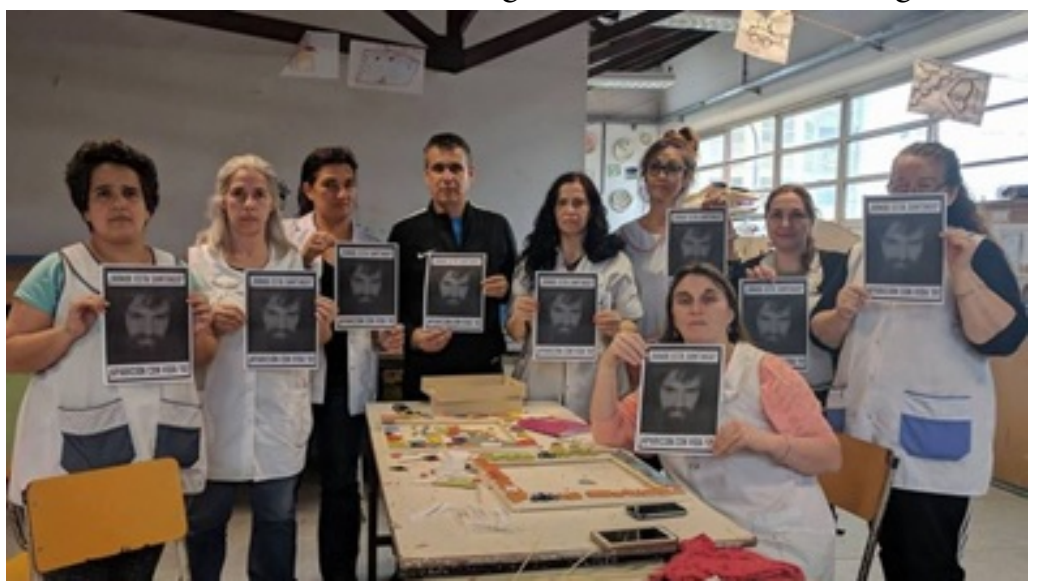

Fuente: https://www.ctera.org.ar/index.php/prensa/noticias-prensa/item/2792-donde-esta-santiago-maldonado-comenzo -hoy-30-de-agosto-dia-internacional-del-detenido-desaparecido-la-campana-nacional-de-ctera-en-todas-las-escuelas-del-pais

La actividad fue criticada públicamente por el ministro de Educación nacional Alejandro Finochiaro, quien el mismo día del lanzamiento de la campaña y por Radio Mitre indicó que se trataba de una "canallada" y manifestó que "deberíamos estar en cada aula para ver cómo es tratado el tema”. Por su parte, la ministra de Educación de la Ciudad de Buenos Aires, Soledad Acuña, señaló en el noticiero de Todo Noticas que se trataba de una utilización política del caso por motivos electorales que beneficiaban al kirchnerismo, al mismo tiempo que llamó a que madres y padres se comunicaran con las instituciones educativas para denunciar cualquier acto de "sobrepolitización". ${ }^{27}$ Por Twitter y Facebook se impulsó una acción bajo el hashtag \#ConMisHijosNo donde se instaba a llamar al teléfono 0800 444-2400 perteneciente al Ministerio de Educación de la Ciudad de Buenos Aires, para denunciar los docentes que mencionaran a Santiago Maldonado. Cabe destacar que esa línea fue abierta en agosto de 2012 por el entonces ministro de dicha cartera Esteban Bullrich, con motivo de la supuesta injerencia de La Cámpora en las escuelas. ${ }^{28}$

Luego, a fines de octubre de 2017, las autoridades del Archivo Nacional de la Memoria prohibieron la exhibición, en la Noche de los Museos, de la escultura "Ausencias" del grupo TAS (Jackie Simsolo y Adriana Albi). Para la institución, el motivo de la censura radicaba en que la obra remitía a Santiago Maldonado (aun cuando la misma había sido realizada dos años antes).

Además de este tipo de acciones de censura tanto sobre la palabra como sobre las imágenes, ocurrieron también actos de iconoclasia: una noticia que cobró cierta relevancia refiere a una de las imágenes pertenecientes a la convocatoria "Santiago, tu mirada nos mira", pegada sobre una de las paredes adyacentes a la Basílica de Nuestra Señora del Rosario y Convento de Santo Domingo, ubicada en el barrio de San Telmo de la Ciudad Autónoma de Buenos Aires, frente a la agencia de noticas Télam. El 21 de julio de 2018, la imagen fue arrancada por un sacerdote perteneciente a dicha iglesia. La secuencia fue fotografiada por varias personas que se encontraban allí. A través de redes sociales, circularon fotos que daban cuenta de la actitud iconoclasta (Figura 13). Este comportamiento violento frente a la presencia de la mirada hecha imagen no fue 
aislado, ya que se habían registrado meses atrás otros casos de ataques a imágenes vinculadas al caso e incluso pintadas para tapar murales, denunciadas por la familia Maldonado, como la fotografía que registra el ataque a un cartel en Lago Puelo, localidad ubicada en Cushamen, provincia de Chubut (Figura 14).

Figura 13. Fotografía de Maximiliano Zurita publicada en Desaparecer la memoria (21 de julio de 2018), ANReD, Ciudad Autónoma de Buenos Aires.

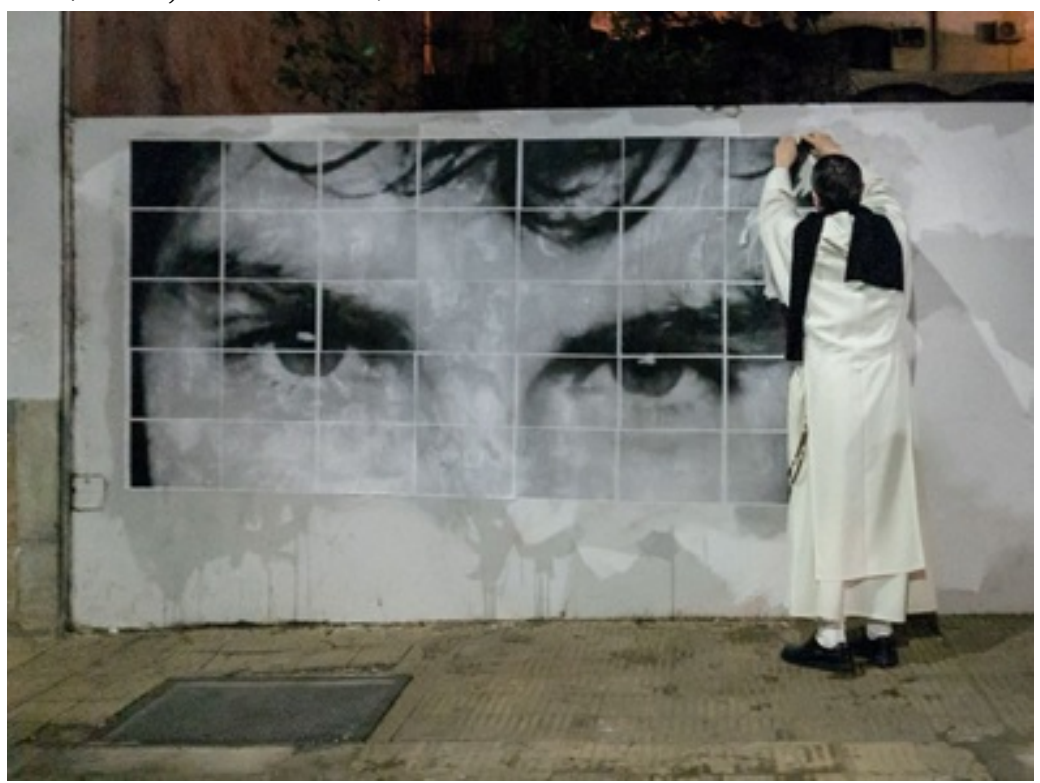

Fuente: Disponible en https://www.anred.org/?p=99931

Figura 14. Fotografía publicada por familiares de Santiago Maldonado en su sitio de Facebook Justicia por Santiago Maldonado . 14 de noviembre de 2017, Lago Puelo, Chubut.

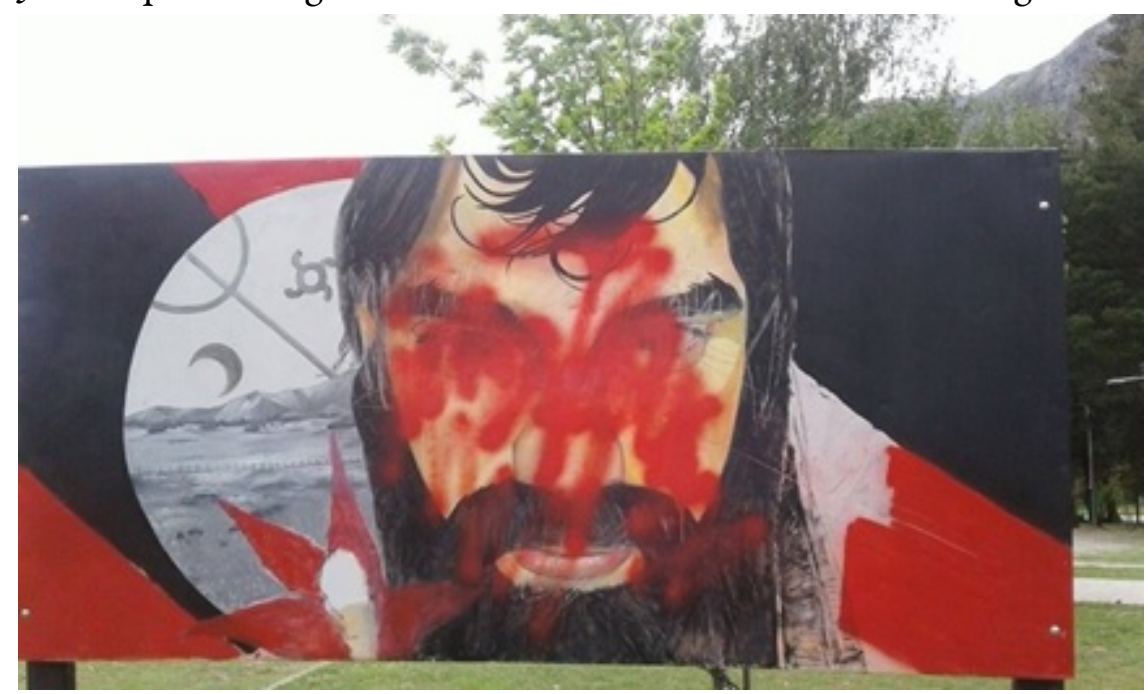

Fuente: https://www.facebook.com/permalink.php?story_fbid=861596214008969\&id=818427001659224

Se puede ver aquí una intervención sobre los ojos de este retrato de Maldonado, evidenciando una de las prácticas habituales de quienes realizan ataques iconoclastas. Este tipo de ataques demuestra la vitalidad que se le atribuye a las imágenes, así como su condición de ser sustitutos de cuerpos (Bredekamp, 2017) ¿Por qué el ataque se centra en la mirada? ¿Por qué dañar dicha imagen? Una posible respuesta ha sido desarrollada por David Freedberg, 
quien argumenta que la tendencia a fusionar la imagen con el cuerpo está en el fundamento de todos los ataques iconoclastas a figuras políticas -y agrego: a víctimas como Maldonado-, es por ello que no pueden ser calificados de ataques simbólicos. Dañar los ojos de un retrato funciona así como un acto equivalente a dañar el propio cuerpo que está en lugar de la imagen, deviniendo un lugar común con larga historia en los ataques a éstas:

La forma más común de mutilación iconoclasta de una imagen es la eliminación o extirpación de los ojos, el signo más claro de la animación inherente a la imagen. Arrancar los ojos es privar a la persona representada del símbolo más importante de la vitalidad y de la capacidad para expresar las emociones asociadas con los seres vivos. Los ojos son a menudo el primer elemento del acto iconoclasta y, en muchos casos, el único y suficiente (Freedberg, 2017, p. 55).

En este campo donde las imágenes devienen sustitutos de cuerpos (el acto de imagen sustitutivo) emerge también un modo de violentar a la víctima y denigrarla propio de la era digital, a partir de la circulación de las fotografías del cadáver de Santiago Maldonado que fueron tomadas por un médico de la Policía Federal Argentina, y publicadas en Twitter y diferentes portales. A modo de burla, estas imágenes sirvieron como material de memes con intenciones risibles por parte de cuentas posicionadas en contra de la familia Maldonado, produciendo un daño que lesiona el derecho a la imagen del fallecido. ${ }^{29}$

\section{Conclusiones}

Las intervenciones que hicieron visible la imagen del rostro de Santiago Maldonado fueron insistiendo en tanto que apariciones en diferentes puntos del país para interpelar al gobierno y agrupar a un movimiento en torno a una causa. A partir de una tradición iconográfica que cruza los activismos artísticos, el fotoperiodismo y los movimientos de derechos humanos, fue posible que la desaparición y muerte del joven pudiera ser reconocida como problema público. El valor que se le asignó a las imágenes muestra que estas exceden largamente la mera representación o bien su carácter de símbolos. Son sobre todo armas de la política y sustitutos de cuerpos que habilitan no solo una serie de rituales de restitución de la humanidad de los muertos (Pita, 2010), sino también una interpelación que invita a comprometerse con un pedido de justicia, y que señalan un antagonismo y, por lo tanto, un conflicto. Las imágenes son también ese terreno donde la política hace su entrada, porque no ilustran nada, tampoco dicen, hacen aparecer cada vez un escenario de conflictos.

\section{Referencias}

Aruguete, N. y Calvo, E. (2017). Una voz imposible de callar: ¿Dónde está Santiago Maldonado. Revista Anfibia. Recuperado de https://www.revistaanfibia.com/un a-voz-imposible-callar-donde-esta-santiago-maldonado/

Austin, J. L. (1990). Cómo hacer cosas con palabras. Barcelona: Paidós.

Benjamin, W. (2019). La obra de arte en la época de su reproductibilidad técnica. Buenos Aires: Godot. 
Boehm, G. (2011). El giro icónico. Una carta. Correspondencia entre Gottfried Boehm y WJ Thomas Mitchell. En A. García Varas (Ed.), Filosofía de la imagen (pp. 57-70). Salamanca: Ediciones Universidad de Salamanca.

Boehm, G. (2014). Decir y mostrar: elementos para una crítica de la imagen. En L. Báez y E. Carrión (Eds.), XXXVI Coloquio Internacional de Historia del Arte. Los estatutos de la imagen, creación manifestación-percepción (pp. 17-40). México: Universidad Nacional Autónoma de México-Instituto de Investigaciones Estéticas.

Bredekamp, H. (2004). Acto de imagen como testimonio y juicio. En M. Flacke (Ed.), Mythen der Nationen. 1945.- Arena der Erinnerungen (pp. 29-66). Berlín: Deutsches Historisches Museum.

Bredekamp, H. (2017). Teoría del acto icónico. Madrid: Akal.

Burucúa, J. E. y Kwiatkowski, N. (2014). "Cómo sucedieron estas cosas" Representar masacres y genocidios. Buenos Aires: Katz.

Capasso, V. y Bugnone, A. (2019). Activismo artístico y memoria: el caso de la desaparición de Santiago Maldonado. Cuadernos de Música, Artes Visuales y Artes Escénicas 14(2). http://doi.org/10.11144/javeriana.mavae14-2.aaym

Castoriadis, C. (2007). La Institución imaginaria de la sociedad. Buenos Aires: Tusquets

Da Silva Catela, L. (2009). Lo invisible revelado. El uso de la fotografía como (re) representación de la desaparición de personas en Argentina. En C. Feld y J. Stites Mor (Eds.), El Pasado que miramos. Memoria e imagen ante la historia reciente. Buenos Aires: Paidós.

Da Silva Catela, L. (2014). No habrá flores en la tumba del pasado. La experiencia de reconstrucción del mundo de familiares de desaparecidos. La Plata: Ediciones Al Margen.

Da Silva Catela, L. (2019). Mirar, desaparecer, morir. Reflexiones en torno al uso de la fotografía y los cuerpos como espacios de inscripción de la violencia. Clepsidra, 6(11), 36-51. Recuperado de https://ri.conicet.gov.ar/handle/11336/126342

Didi-Huberman, G. (2009). La imagen superviviente. Historia del arte y tiempo de los fantasmas según Aby Warburg. Madrid: Abada.

Donoso Macaya, A. (2016). Persistencias del retrato fotográfico. Revista Atlas. Recuperado en https://atlasiv.com/2016/07/20/persistencias-del-retrato-fotogr afico/

Féliz, M. (2016). Arte piquetero en la convergencia: apropiación artística de las TIC en torno a la masacre de Avellaneda. En A. Torres y M. Pérez Balbi (Eds.), Visualidad y dispositivo(s). Arte y técnica desde una perspectiva cultural. Buenos Aires: Ediciones Universidad Nacional de General Sarmiento.

Foucault, M. (2002). Las palabras y las cosas. Una arqueología de las ciencias humanas. Buenos Aires: Siglo XX.

Fortuny, N. (2014). Memorias fotográficas. Imagen y dictadura en la fotografía argentina contemporánea. Buenos Aires: La Luminosa.

Freedberg, D. (2009). El poder de las imágenes. Estudios sobre la historia y la teoria de la respuesta. Madrid: Cátedra.

Freedberg, D. (2017). Iconoclasia. Historia y psicología de la violencia contra las imágenes. Buenos Aires: Sans Soleil.

Gamarnik, C. (2010). La construcción de la imagen de las Madres de Plaza de Mayo a través de la fotografía de prensa. Afuera: estudios de critica cultural, (9), 1-16. Recuperado de https://www.academia.edu/6905172/La_construcci\%C3\%B3n_de_la_imag 
en_de_las_Madres_de_Plaza_de_Mayo_a_trav\%C3\%A9s_de_la_fotograf\%C3 \%ADa_de_prensa

Gamarnik. C. (2020) El fotoperiodismo en Argentina. De Siete Días Ilustrados (1965) a la Agencia SIGLA (1975). Buenos Aires: Fundación Alfonso y Luz Castillo.

Gayol, S. y Kessler, G. (2018). Muertes que importan: una mirada sociohistórica sobre los casos que marcaron la Argentina reciente. Buenos Aires: Siglo XXI.

Ginzburg, C. (2001). 'Your Country Needs You': a Case Study in Political Iconography. History Workshop Journal, 52(1), 1-22. Recuperado de https://academic.oup.co $\mathrm{m} / \mathrm{hwj} /$ article-abstract $/ 52 / 1 / 1 / 553549$ ? redirectedFrom=fulltext

Halbwachs, M. (2004). Memoria colectiva y memoria individual. En Autor, La memoria colectiva (pp. 25-52). Zaragoza, Prensas Universitarias de Zaragoza.

Jelin, E. (2010). ¿Víctimas, familiares o ciudadano/as? Las luchas por la legitimidad de la palabra. En E. Crenzel (Coord.), Los desaparecidos en la Argentina. Memorias, representaciones e ideas (1983-2008) (pp.227-249). Buenos Aires: Biblos.

Jelin, E. (2018). La lucha por el pasado. Cómo construimos la memoria social. Buenos Aires: Siglo XXI.

Longoni, A. (2009). Activismo artístico en la última década en Argentina: algunas acciones en torno a la segunda desaparición de Jorge Julio López. Revista Errata, (0), Bogotá, pp. 16-35.

Longoni, A. (2010). Fotos y siluetas: políticas visuales en el movimiento de derechos humanos en Argentina. Afterall Journal (25). Recuperado de https://www.afterall.org/article/photographs-and-silhouettes-visual-politicsin-the-human-rights-movement-of-argentina

Mazzuchini, S. (2019). De la fotografía a los muros: el rol del fotoperiodismo y el arte político en la construcción de las figuras de Darío Santillán y Maximiliano Kosteki (2002-2017). Clepsidra, 6(11), 52-69. Recuperado de https://www.ides.org.ar/si tes/default/files/attach/clepsidra_11_dobles_baja_opt.pdf

Mitchell, W.J.T. (2009). Teoría de la imagen. Madrid: Akal.

Noble, A. (2008). Travelling theories of family photography and the material culture of human rights in Latin America. Journal of Romance Studies, 8(1), 43-59.

Pérez Balbi, M. (2016). Reenvíos. Cruces entre activismo artístico e Internet en la Argentina (2005-2011). En A. Torres y M. Pérez Balbi (Eds.), Visualidad y dispositivo(s). Arte y técnica desde una perspectiva cultural (pp. 171-186). Buenos Aires: Ediciones Universidad Nacional de General Sarmiento.

Pita, M. (2010). Formas de viviry formas de morir. El activismo contra la violenciapolicial. Buenos Aires, Argentina: Del Puerto- Centro de Estudios Legales y Sociales.

Pollak, M. (2006). Memoria, olvido, silencio. En Autor (Comp.), Memoria, olvido, silencio. La producción social de identidades frente a situaciones limite (17-31). La Plata: Ediciones Al Margen.

Rancière, J. (2008). El desacuerdo. Política y filosofía. Buenos Aires: Nueva Visión.

Searle, J. (1994). Actos de habla. Ensayo de filosofia del lenguaje. Buenos Aires: Planeta.

Warburg, A. (2005). Introducción. En Autor (Ed.), Bilderatlas Mnemosyne pp. (3-6). Berlín: Akademie Verlag.

Warburg, A. (2014). La pervivencia de las imágenes. Buenos Aires: Miluno. 


\section{Notas}

1 Militante peronista que sufrió dos desapariciones. La primera, durante la última dictadura militar, ocurrió en 1976, cuando fue secuestrado en su casa de Los Hornos, La Plata. Permaneció detenido en un centro clandestino de detención (CCD) a cargo del represor Miguel Etchecolatz. Fue liberado el 25 de junio de 1979. Ya en 2006, fue nuevamente desaparecido el 18 de septiembre, un día antes de que fuera sentenciado Etchecolatz por delitos de lesa humanidad. López había sido testigo y querellante en el juicio.

2 Joven de 16 años desaparecido el 31 de enero de 2009 mientras volvía a su casa en Lomas del Mirador. Fue visto por última vez cerca de un destacamento policial de la zona, donde el 22 de septiembre de 2008 había sido detenido y torturado por negarse a robar para la policía. Luego de movilizaciones y reclamos se abrió una causa por desaparición forzada y ocho policías implicados fueron pasados a disponibilidad aunque luego fueron reincorporados en otras jurisdicciones. El cuerpo de Luciano Arruga se encontró el 17 de octubre -al igual que Santiago Maldonado- de 2014, enterrado como cuerpo no identificado en el Cementerio de la Chacarita. El 15 de mayo de 2015 fue condenado a prisión Julio Torales, luego de que se probara que torturó a Luciano en el destacamento donde fue detenido.

3 Estudiante de periodismo de 23 años, detenido de manera ilegal, torturado y asesinado por policías de la comisaría nueve de La Plata, el 17 de agosto de 1993. Por el caso fueron condenados a cadena perpetua los policías Justo José López y Walter Abrigo el 17 de mayo de 1999. Se trató del primer juicio de un desaparecido en democracia.

4 Rancière elabora una concepción de las imágenes diferente a las sostenidas por los autores agrupados bajo el ikonische Wende, ya que no cree que sean portadoras de tal vitalidad. Pero aún en esa diferencia su filosofía constituye un aporte clave, ya que a partir de la vinculación que realiza entre estética y política, permite pensar la disputa en el terreno de lo sensible.

5 Sergio Maldonado indicó el 22 de abril de 2019, en una entrevista para la radio Futurock, que su hermano era anarquista. Del mismo modo, amigos y compañeros que lo conocían aseguran que esa era su inscripción política. En la web que la familia diseñó para seguir militando por la causa, se encuentra un texto de una de sus libretas, donde se expresa ese posicionamiento anarquista. Puede consultarse en https://www.santiag omaldonado.com/palabras-de-santiago/

6 Por cuestiones de espacio no se trabajará aquí sobre el caso de Rafael Nahuel, pero es preciso mencionar su asesinato como parte del mismo problema que se está tratando.

7 La remisión a la figura de la desaparición en Argentina lleva a la última dictadura militar, que persiguió, secuestró, torturó y ,en la mayoría de los casos, efectuó desapariciones de los cuerpos de las víctimas por razones políticas. Como indica da Silva Catela (2014), la singularidad de la figura del desaparecido remite a una triple falta: la del cuerpo, la del duelo por parte de familiares y la de una sepultura.

8 En un informe brindado el 16 de agosto a la Comisión de Seguridad y Narcotráfico del Senado para evacuar dudas sobre el accionar de Gendarmería en el contexto de la desaparición de Maldonado, Patricia Bullrich indicó: "Yo no voy a hacer la injusticia de querer tirar a un gendarme por la ventana" porque "esa es la fácil, la que siempre hicieron", en referencia clara al kirchnerismo y su política de derechos humanos. Luego la ministra encabezaría la defensa del oficial Luis Chocobar, policía procesado por asesinar a Pablo Kukok, quien había asaltado a un turista.

9 Mauricio Macri: "Conmigo se acaban los curros en derechos humanos" (8 de diciembre de 2014). La Nación. Versión digital disponible en https://www.lanacion.com.ar/politica/mauricio-macri-conmigo-se-acaban-los-cur ros-en-derechos-humanos-nid1750419/

10 La entrevista donde declaró Mauricio Macri fue realizada por Buzzfeed (10 de agosto de 2016). Puede consultarse en su página de Facebook: https://www.facebook.com/w atch/live/?v=1102146709840102\&ref=external

11 Juan José Gómez Centurión, sobre los desaparecidos: "No es lo mismo 8.000 verdades que 22.000 mentiras" (29 de enero de 2017), La Nación, recuperado 
de https://www.lanacion.com.ar/politica/juan-jose-gomez-centurion-sobre-los-desap arecidos-son-22-mil-mentiras-nid1980180/ y "Lopérfido: "Entre todos los males que hizo el kirchnerismo, el peor fue crear fanáticos" (13 de febrero de 2017) Perfil. Recuperado de https://www.perfil.com/noticias/politica/loperfido-entre-todos-losmales-que-hizo-el-kirchnerismo-el-peor-fue-crear-fanaticos.phtml

12 Cabe destacar que circularon diversos retratos de Maldonado, pero esta fotografía captura el aspecto que más se acerca al que tuvo, según testigos, los últimos días que fue visto. Véase "Los últimos días de Santiago: cuatro testimonios que desmienten la hipótesis del gobierno" (24 de agosto de 2017). La Vaca. Recuperado de http://lavaca.org/notas/los-ultimos-dias-de-santiago-cuatro-testimon ios-que-desmienten-la-hipotesis-del-gobierno/

13 El grupo se presenta en su web https://somosmafia.com como "un colectivo fotográfico que surgió en noviembre de 2012. A partir de la firma colectiva y el trabajo colaborativo, concebimos la labor fotográfica como un espacio de exploración artística que busca interpelar al espectador desde una doble perspectiva: informativa y estética."

14 Como indica Longoni (2009), el activismo artístico puede ser definido como "producciones y acciones, muchas veces colectivas, que abrevan en recursos artísticos con la voluntad de tomar posición e incidir de alguna forma en el territorio de lo político." (p. 18). Sobre las acciones alrededor de Darío Santillán y Maximiliano Kosteki, véase Féliz (2016), Pérez Balbi (2016) y Mazzuchini (2019). Para el caso de Julio López, el ya citado de Longoni.

15 Para un análisis sobre la incidencia de Twitter en la conversación digital sobre el caso, véase Aruguete y Calvo (2017).

16 Noble recupera la observación de Diana Taylor, para quien estas movilizaciones exhiben una transformación de los cuerpos de Madres y Abuelas en "soportes ambulantes" para que circulen los rostros de quienes fueron secuestrados y asesinados por el Estado. Sobre el caso de Chile, Donoso Macaya (2016) destaca el trabajo de Nelly Richard para pensar la insistencia del retrato fotográfico en este tipo de reclamos.

17 Vinculándolo con Warburg y Freud, este concepto viene a intentar pensar esas pervivencias de las imágenes en tanto que síntomas: "Pero equé es un síntoma desde el punto de vista del tiempo histórico? Sera, en el contexto que nos hemos dado, la ritmicidad muy particular de un acontecimiento de supervivencia: efracción (surgimiento del Ahora) y retorno (surgimiento del Antaño) mezclados. O dicho de otro modo, será la concomitancia inesperada de un contratiempo y de una repetición" (Didi-Huberman, 2009, p. 152).

18 La posición de Benjamin sobre la triturazión del aura por parte de la reproductibilidad técnica ha recibido críticas de David Freedberg (2009), quien sostiene -a propósito de las imágenes religiosas- que la reproducción técnica nunca fue un impedimento para que estas sigan evocando su poder taumatúrgico.

19 Reivindicando el anonimato, la propuesta surgió a partir de un espacio asambleario compuesto por fotógrafos, periodistas, y otros militantes. La iniciativa circuló en portales de comunicación alternativa como la Agencia de Noticias Red-Acción (ANRed), el periódico digital Pausa, y en correos electrónicos.

20 Convocatoria a la acción "Santiago, tu mirada nos mira" (2018). Recuperado de http $\mathrm{s://tumiradanosmira.wordpress.com/}$

21 En la introducción a su Atlas Mnemosyne Warburg (2005) describe ese Denkraum de este modo: "la creación consciente de distancia entre sí mismo y el mundo exterior bien puede designarse como el acto fundacional de la civilización humana" (p. 1).

22 La rostridad es un tipo de gramática que opera sobre el cuerpo, cifrándolo e identificandolo. El concepto fue desarrollado por Deleuze y Guattari (2008) para dar cuenta de los regímenes de poder que producen rostros, tomando a Cristo como el modelo ejemplar. Bajo este concepto puede comprenderse este proceso de percepción que hace que fácilmente reconozcamos una forma rostritaria. El concepto remite a dos operaciones sobre los cuerpos: la subjetivación, expresada bajo la forma agujeros negros (ojos y boca), y la pared blanca, donde opera el significante que coagula el sentido. Ambos procesos producen una segmentación de la cabeza con respecto a un cuerpo que se rostrifica, es decir, se vuelve un cifrado fácil de identificar. Este agenciamiento 
maquínico es un dispositivo que regula las formas legítimas que pueden hacer emerger una rostridad.

23 También puede consultarse otra versión con el retrato en color y una reflexión de la autora de la imagen en Redacción 351. Disponible en: https://redaccion351.com/anu ario/noe-gaillardou/

24 La bandera se situaba alrededor de otras imágenes que habían sido colocadas en el marco de una acción conjunta de diferentes grupos de activistas. Véase Arte Urgente en la ex ESMA (29 de septiembre de 2017). Página 12, fuente: https://www.paginal 2.com.ar/65954-arte-urgente-en-la-ex-esma

25 Las investigadoras Verónica Capasso y Ana Bugnone también destacan estos vínculos a partir de una interesante observación sobre la pregunta-consigna ¿Dónde está Santiago Maldonado?: "Esta pregunta parece tener dos sentidos reconocibles: por un lado, se refiere a un interlocutor válido, el Gobierno, la Gendarmería o el propio empresario Benetton, es decir, que se produce con la intención de ser respondida por quienes son considerados responsables; por otro lado, resuena en el lugar de una pregunta retórica que remite a las desapariciones del pasado reciente, la mayoría de ellos jamás encontrados. Es preciso decir también que no solo hay un enlace con ese pasado reciente, sino que además con esa pregunta se vincula la desaparición de Maldonado con otros casos sucedidos en democracia" (2019, p. 37).

26 Puede consultarse "Caso Maldonado en las escuelas: los padres, entre la indignación y el respaldo” (30 de agosto de 2017). Clarín. Recuperado de https://www.clarin.com/s ociedad/caso-maldonado-escuelas-padres-indignacion-respaldo_0_ry32n84tb.html o bien "Ctera respondió a las críticas del Gobierno a la campaña por Maldonado“Temen al debate en las aulas” (31 de agosto de 2017). Página 12. Recuperado https://www.p agina12.com.ar/59932-temen-al-debate-en-las-aulas

27 Soledad Acuña acusó a la CTERA por el instructivo: "Usan los contenidos para una disputa eleccionaria" (30 de agosto de 2017). Todo Noticias. Recuperado de https://tn.com.ar/sociedad/la-desaparicion-de-santiago-maldonado-soledad-acun a-avalo-el-tratamiento-del-caso-en-las-escuelas_816893/

28 Activa la Ciudad un 0800 para denunciar "intromisión política" de La Cámpora en escuelas" (16 de agosto de 2012), La Nación. Recuperado de https://www.lanacion.com.ar/politica/activan-un-0800-para-denunciar-la-introm ision-de-la-campora-en-las-escuelas-nid1499765/

29 El médico legalista que publicó las fotografías fue condenado a un año y seis meses de prisión en suspenso por el delito de revelación de secreto oficial. En la sentencia del Juzgado Federal de Esquel, la abogada de los Maldonado fundamentó el pedido de que las imágenes sean eliminadas de los motores de búsqueda a partir del derecho a la imagen: "reiteró lo expresado por Sergio Maldonado, en cuanto se requiera a los motores de búsqueda de Internet que sean eliminadas las imágenes obtenidas de manera ilegal, para que no sean reproducidas, fundamentando el pedido en el Derecho a la Imagen consagrado en el art. 53 del Código Civil y Comercial de la Nación.” Puede consultarse la sentencia en https://www.cij.gov.ar/nota-36041-Sentencia-del-Juzgado-Federal-de-Esquel-encausa--Aguiar--Werther-Augusto-s--violaci-n-de-secretos-.html 